Prihatin. et.al. Peningkatan Ekonomi Masyarakat Desa Sei Rotan Melalui Optimisasi Manajemen Usaha Kelompok Kerupuk Rengginang

\title{
PENINGKATAN EKONOMI MASYARAKAT DESA SEI ROTAN MELALUI OPTIMISASI MANAJEMEN USAHA KELOMPOK KERUPUK RENGGINANG
}

\author{
Prihatin Lumbanraja ${ }^{1)}$, Arlina Nurbaity Lubis ${ }^{2)}$, Beby Kendida Hasibuan ${ }^{3)}$,Amlys Syahputra Silalahi ${ }^{4)}$ \\ ${ }^{1)}$ Fakultas Ekonomi dan Bisnis, Universitas Sumatera Utara \\ Email: titinlumbanraja@yahoo.com \\ ${ }^{2)}$ Fakultas Ekonomi dan Bisnis, Universitas Sumatera Utara \\ Email: arlina@usu.ac.id \\ 3) Fakultas Ekonomi dan Bisnis, Universitas Sumatera Utara \\ Email: bebykendida08@gmail.com \\ 4) Fakultas Ekonomi dan Bisnis, Universitas Sumatera Utara \\ Email: amlysku@gmail.com
}

\begin{abstract}
Abstrak
Tingginya angka pencari kerja memaksa setiap individu untuk berfikir kreatif mencari lapangan kerja baru. Salah satu lapangan pekerjaan yang dapat mendorong pengurangan angkatan kerja adalah dengan wirausaha. Hanya saja sampai dengan saat ini wirausaha masih didominasi oleh ibu rumah tangga sebagai salah satu cara untuk memperoleh tambahan penghasilan. Dalam kegiatannya ada beberapa kendala yang dihadapi oleh pelaku wirausaha ini yaitu kendala produksi dan kendala pemasaran. Dimana kendala produksi adalah mengenai jumlah produksi yang masih sangat terbatas disebabkan karena alat produksi yang belum memadai. Kendala dari aspek pemasaran adalah kemasan produk yang kurang menarik dan juga masih tebatasnya lokasi pemasaran produk. Kegiatan pengabdian ini mensiyalir peningkatan jumlah produksi mitra dan memperbaiki kualias kemasan serta aktivitas promosi mitra. Tim pengabdian memberikan label dan kartu nama sebagai dasar kegiatan pemasaran mitra. Selain itu mitra juga mempelajari pemasaran secara online. Hasil kegiatan pengabdian secara umum sangat memuaskan. Mitra berkembang dan pendapatan masyarakat meningkat. Mitra mengalami peningkatn baik dari sisi produktivitas maupun permintaan.
\end{abstract}

Kata Kunci: Produksi, Pemasaran, Penigkatan Pendapatan, Keberlangsungan Usaha.

\section{PENDAHULUAN}

\subsection{Latar Belakang Kegiatan Pengabdian}

Kewirausahaan merupakan bekal dalam membangun perkembangan usaha dan roda pembangunan ekonomi di Dunia. Kehadiran kewirausahaan secara signifikan menghasilkan banyak lapangan kerja baru yang mendorong berbagai indikator pembangunan.Kewirausahaan membangun pendapatan nasional dan memangkas angka pengangguran. Laporan dari Badan Pusat Statistik Indonesia (2016) menyatakan bahwa tingkat rasio kewirausahaan di Indonesia telah mencapai angka 3,1\% dari penduduk, tumbuh dari sebelumnya pada tingkat
1,67\% pada tahun 2014. Tamizharasi dan Panchanatham (2010) memberikan indikasi angka minimal $2 \%$ dalam rasio kewirausahaan suatu Negara sebagai dasar masyarakat sejahtera. Dari standar ini, Indonesia berhasil melampui kriteria minimum tersebut. Sayangnya, kewirausahaan Indonesia masih jauh di bawah Negara tetangga seperti Malaysia (5\%), dan Singapura (7\%).

Peran dari usaha mikro, kecil, dan menengah dalam pertumbuhan dan percepatan pergerakan roda pembangunan suatu negara. Agarwal and Ashwandi (2008) menyatakan bahwa jumlah UMKM di dunia mencapai $99,7 \%$ dari seluruh usaha di dunia. Ussahawanitchaki (2012) 
mengemukakan bahwa kehadiran UMKM di suatu negara merupakan katalis pembangunan, baik di negara berkembang maupun negara maju. Peran utama dari UMKM adalah penyerapan tenaga kerja, mendukung usaha besar, serta membarikan kontribusi terbesar dalam GDP. Kontribusi UMKM umumnya lebih dari 50\% dari total GDP serta memberikan penyerapan lebih dari $65 \%$ bagi suatu negara. Olughor (2015) menyatakan bahwa UMKM berkontribusi hingga $75 \%$ penyerapan tenaga kerja dunia. Kementerian Kopersi dan Usaha Mikro, Kecil dan Menengah (2015) mendata sumbangan UMKM Indonesia terhadap GDP adalah sebesar 57,48\% dan menyerap 96,99\% tenaga kerja pada tahun 2013. Peranan UMKM di negara berkembang semakin besar mengingat banyak dari UMKM mampu dan bersedia menyerap banyak unskilled labor (Bhhatia-Panthaki, 2007). Pertumbuhan UMKM di suatu negara mampu mengurangi kemiskinan di negara tersebut (Ayyagari et al. 2007).

Meskipun UMKM memiliki peran penting dalam pertumbuhan dan perkembangan ekonomi, sebagai contoh menyediakan lebih banyak kesempatan kerja dan menekan tingkat pengangguran, banyak ketidakpastian menyelimuti kelangsungan usaha dari kalangan masyarakat. UMKM memiliki kegagalan yang lebih tinggi atau tingkat gagal bayar dibandingkan dengan perusahaan besar meskipun mereka dianggap sebagai tulang punggung, mesin untuk pertumbuhan ekonomi (Bloch dan Bhattacharya, 2016; Lo et al., 2016).

Saat ini pelaku wirausaha (UMKM) yang terbesar adalah para ibu rumah tangga. Dimana wirausaha dinggap dapat membantu pendapatan rumah tangganya. Ibu rumah tangga memegang peranan penting dalam membina kesejahteraan keluarga. Ibu rumah yang bijak akan memikirkan beberapa cara dalam memenuhi kebutuhan setiap anggota keluarganya. Meskipun pada mulanya peranan wanita adalah sebagai ibu rumah tangga, banyak dari wanita mulai menjalankan peran ganda sembari membantu nafkah keluarga dari suaminya. Kondisi ini mendorong banyak wanita khususnya ibu rumah tangga menjabat sebagai pelaku usaha baru.

Kebanyakan dari para ibu rumah tangga memanfaatkan keahlian yang dimilikinya untuk memperoleh tambahan pemdapatan. Salah satu cara yang paling banyak dilakukan oleh ibu-ibu rumah tangga tersebut adalah dengan berwirausaha. Inti dari kewirausahaan adalah kemampuan untuk menciptakan sesuatu yang baru dan berbeda melalui pemikiran kreatif dan tindakan inovatif demi terciptanya peluang.

Salah satu daerah dimana para ibu rumah tangganya menjadi wirausaha adalah Gang Sopyan Desa Sei Rotan Batang Kuis di Deli Serdang. Kebanyakan ibu rumah tangga disana memiliki usaha sampingan untuk membantu dalam pemenuhan kebutuhan rumah tangganya. Adapun usaha yang dilakukan oleh para ibu rumah tangga tersebut antara lain sebagai berikut:

Tabel 1 Data Jumlah Usaha

\begin{tabular}{clc}
\hline No & \multicolumn{1}{c}{ Jenis Usaha } & Jumlah \\
\hline \hline 1 & $\begin{array}{l}\text { Usaha Membuat } \\
\text { Rengginang }\end{array}$ & 5 Orang \\
\hline 2 & $\begin{array}{l}\text { Usaha Membuat } \\
\text { Emping }\end{array}$ & 3 Orang \\
\hline 3 & $\begin{array}{l}\text { Usaha Membuat } \\
\text { Payet }\end{array}$ & 1 Orang \\
\hline 4 & Usaha Menjahit & 1 Orang \\
\hline 5 & Membuka Kedai & 3 Orang \\
\hline \hline & Jumlah & 12 Orang \\
\hline
\end{tabular}

Sumber : Survei Tim (2017)

Usaha pembuatan rengginang paling banyak diminati oleh penduduk para ibu rumah tangga disebabkan karena banyaknya permintaan dari masyarakat akan produk tersebut. Sehingga mitra dari pengabdian ini adalah pelaku usaha pembuatan rengginang. 
Prihatin. et.al. Peningkatan Ekonomi Masyarakat Desa Sei Rotan Melalui Optimisasi Manajemen Usaha Kelompok Kerupuk Rengginang

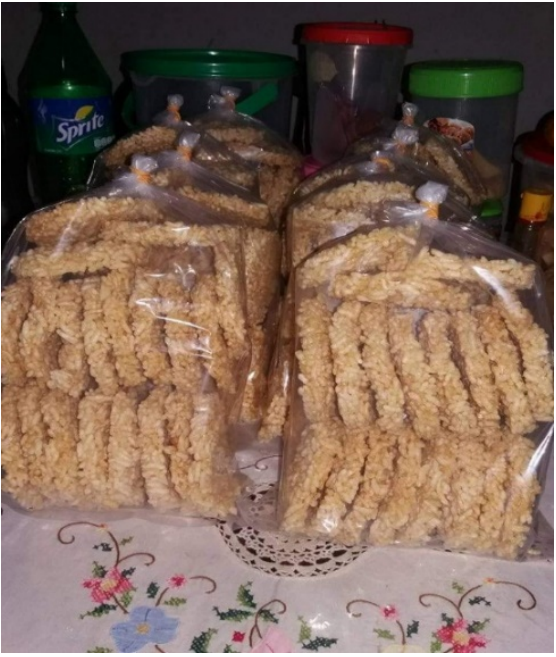

Gambar 1.1. Kerupuk Rengginang Mitra 1.2 Permasalahan Mitra

Sampai dengan saat ini mitra hanya menjual produknya di sekitar lokasi tempat tinggal saja, dan adakalanya mereka tidak mampu memenuhi permintaan konsumen karena jumlah produksi yang masih terbatas dan masih memanfaatkan tenaga matahari untuk mengeringkan kerupuk. Jumlah produksi yang terbatas disebabkan karena peralatan produksi yang masih sederhana dan juga peralatan produksi yang digunakan masih menggunakan peralatan rumah tangga sederhana dengan kapasitas yang terbatas. Kondisi ini yang menyebabkan mereka membatasi produksi hariannya karena jika mereka ingin memperoduksi dalam sekala banyak, mereka harus memasak bahan secara berulang-ulang yang sudah tentu akan memakan banyak waktu dan ditakuti kerupuk rengginang tidak dapat terjemur matahari yang berakibat pada kerupuk menjadi gagal dan akan menyebabkan kerugian pada mitra.

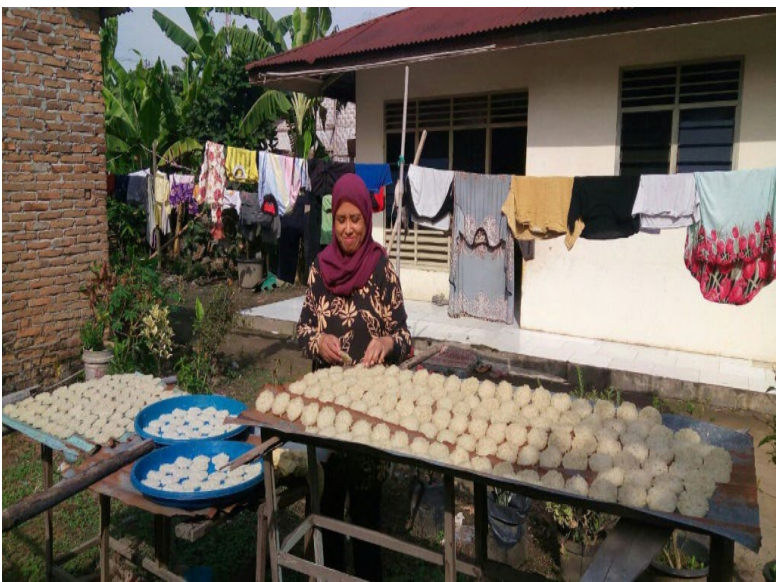

Gambar 2. Proses Penjemuran Rengginang

Para mitra juga hanya mampu memasarkan produk mereka ke kedaikedai disekitar lokasi karena untuk memasuki pasar yang lebih luas mereka belum mampu. Para mitra pernah mencoba untuk menawarkan produknya ke kedai yang lebih besar, akan tetapi produk tersebut ditolak karena dinilai tidak menarik dan tidak layak jual. Hal ini disebabkan pengemasannya yang kurang dan juga kurangnya pengetahuan mereka akan kemampuan menjual produknya. Dalam menjalankan usahanya, mitra dihadapkan pada masalah bagaimana memasarkan produknya agar dikenal orang banyak. Saat ini mitra hanya mengandalkan pemasaran dari mulut ke mulut dan pemasaran dengan cara rekomendasi teman. Hal ini tentunya tidak akan memberikan hasil yang maksimal. Dalam era digital dengan memanfaatkan media sosial, kita dapat memperoleh produk dari dalam dan luar negeri hanya dalam hitungan menit saja. Hal ini merupakan peluang yang baik untuk dapat mengembang usaha. Sayangnya, kebanyakan dari pelaku usaha tidak memiliki dan mengetahui mengenai media sosial.

\subsection{Solusi yang Ditawarkan}

Tujuan dari kegiatan pengabdian pada masyarakat yang diajukan dalam proposal ini adalah pemberdayaan masyarakat melalui pengoptimalan potensi yang 
Prihatin. et.al. Peningkatan Ekonomi Masyarakat Desa Sei Rotan Melalui Optimisasi Manajemen Usaha Kelompok Kerupuk Rengginang

dimiliki mitra serta membangun semangat pancasila untuk saling menolong antar masyarakat. Permasalah mitra terbagi atas dua bagian yaitu masalah produksi dan masalah masalah pemasaran. Sehingga solusi yang ditawarkan juga terbagi atas solusi untuk masalah produksi dan solusi untuk masalah pemasaran.

Solusi yang ditawarkan pada masalah produksi adalah dengan memberikan pelatihan bagaimana manajemen produksi yang baik. Selain itu mitra juga diberikan bantuan alat untuk kegiatan produksi. Solusi yang ditawarkan pada masalah pemasaran adalah dengan memberikan pelatihan bagaimana pengemasan produk yang baik dan juga pelatihan untuk penggunaan media sosial dalam rangka pemasaran produk

\section{PELAKSANAAN KEGIATAN}

\subsection{Pendekatan Pengabdian}

Kegiatan pengabdian dilaksanakan secara teratur berdasarkan tahapan-tahapan pelaksanaan baik dari bidang produksi dan bidang pemasaran karena kedua bidang ini saling terkait satu dengan yang lainnya. Pelatihan proses produksi. Pada tahap ini mitra diberikan pengetahuan bagaimana proses produksi yang sebaiknya dilakukan. Pada proses ini mitra juga diberitahukan mengenai bagaimana menghitung stock yang ada bagaimana agar EOQ untuk bahan baku dapat dijaga. Pemberian bantuan alat produksi guna menunjang penambahan jumlah produksi kerupuk rengginang. Pelatihan packaging yang baik. Pelatihan dilakuakan agar kemasan dari produk baik itu produk mentah maupun produk masak menjadi lebih baik dan menarik. Sehingga dapat dipasarkan ke toko yang lebih besar. Kamasan yang menarik juga akan meningkat harga jual produk yang berdampak pada peningkatan keuntungan pelaku usaha. Pemberian bantuan bahan packaging akan membantu mitra dalam mengemas produk dengan lebih baik. Pelatihan kemampuan menjual.
Pada tahap ini mitra diberikan masukan akan pentingnya promosi dan bagaimana menjual produk dengan lebih baik. Salah satu cara yang dapat dilakuakan untuk memasarkan produk dengan media sosial. Selain harganya yang murah, media sosial juga dapat diakses oleh banyak orang dan tidak terbatas ruang dan waktu. Pembuatan media sosial bagi mitra.

Metode pendekatan yang dilakukan adalah berdiskusi dengan mitra mengenai masalah apa saja yang menjadi kendala dalam produksi dan pemasaran produk, maka selanjutnya adalah memberikan peralatan apa saja yang dibutuhkan mitra dalam menunjang proses produksi dan pemasaran agar menjadi lebih baik. Pemberian peralatan yang dibutuhkan mitra diharapkan dapat meningkatkan proses produksi dan juga membuat waktu produksi menjadi lebih singkat. Selain itu dengan memberikan pelatihan pemasaran dengan memanfaatkan media sosial dan perbaikan packaging menjadi lebih menarik diharapkan akan membantu meningkatkan volume penjualan mitra.

\subsection{Ipteks yang Diberikan}

Komponen ipteks yang diberikan kepada mitra berkaitan dengan pengembangan pola pikir dan perilaku mitra bersama anggotanya dalam melaksanakan kegiatan usaha yang lebih efektif dan efisien. Ipteks yang diberikan meliputi:

a. Ipteks produksi

Ipteks ini membangun pelaksanaan kegiatan produksi yang efektif dan efisien. Efektif dalam pengertian penggunaan sumber daya semaksimal mungkin. Efisien dalam pengertian penggunaan sumber daya secara tepat guna. Pemberian ipteks produksi bertujuan untuk meningkatkan produktivitas dari mitra.

b. Promosi

Ahli pemasaran, Kotler dan Keller (2012) mengemukakan bahwa promosi adalah usaha yang dilakukan pemasar 
Prihatin. et.al. Peningkatan Ekonomi Masyarakat Desa Sei Rotan Melalui Optimisasi Manajemen Usaha Kelompok Kerupuk Rengginang

untuk mempengaruhi pihak lain agar berpatisipasi dalam kegiatan pertukaran barang atau jasa. Promosi juga merupakan usaha mengkomunikasikan informasi yang bermanfaat tentang suatu usaha atau produk dan jasa untuk mempengaruhi pembeli potensial. Promosi tidak hanya membicarakan produk, harga produk dan pendistribusian produk tetapi juga mengkomunikasikan produk kepada konsumen agar produk itu terkenal dan ujung ujungnya dibeli

\subsection{Kontribusi Mitra}

Mitra mampu dan telah memanfaatkan peralatan produksi yang diberikan secara optimal guna meningkatkan jumlah produksi dan mempersingkat waktu produksi. Selain itu mitra juga berpartisipasi dan berperan aktif dalam penggunaan media sosial untuk pemasaran dan juga membuat packaging kerupuk rengginang yang lebih menarik sehingga konsumen tertarik membelinya. Apabila terjadi situasi di luar rencana pengabdian, mitra dapat berkomunikasi dengan tim pengabdian untuk mencari solusi atas situasi yang terjadi.

\section{HASIL YANG DICAPAI}

\subsection{Evaluasi Perubahan pada Mitra}

Salah satu target dari kegiatan pengabdian ini adalah perubahan perilaku pada mitra terkait dengan ipteks yang diberikan. Berkaitan dengan hal tersebut, Tabel 1 merangkup perubahan yang terjadi pada mitra. Tabel 1 membandingkan antara situasi awal dengan hasil evaluasi kegiatan pengabdian.

Tabel 2 Evaluasi Kemajuan Mitra

\begin{tabular}{|c|c|c|}
\hline Aspek & $\begin{array}{c}\text { Perkembangan } \\
\text { Mitra }\end{array}$ & Capaian \\
\hline $\begin{array}{l}\text { Teknis } \\
\text { Produksi }\end{array}$ & $\begin{array}{l}\text { Mitra } \\
\text { menyisihkan } \\
\text { pendapatan } \\
\text { usaha untuk } \\
\text { memperoleh alat } \\
\text { pengering yang }\end{array}$ & $\begin{array}{l}\text { Perubahan } \\
\text { perilaku untuk } \\
\text { mendukung } \\
\text { usaha sendiri } \\
\text { sangat baik }\end{array}$ \\
\hline
\end{tabular}

\begin{tabular}{|c|c|c|}
\hline Aspek & $\begin{array}{c}\text { Perkembangan } \\
\text { Mitra }\end{array}$ & Capaian \\
\hline & $\begin{array}{l}\text { membantu } \\
\text { produksi saat } \\
\text { cuaca tidak } \\
\text { mendukung }\end{array}$ & \\
\hline $\begin{array}{l}\text { Diferensiasi } \\
\text { Produk }\end{array}$ & $\begin{array}{lr}\text { Mitra } & \text { mampu } \\
\text { dan semangat } \\
\text { dalam } \\
\text { mengembangkan } \\
\text { produk yang } \\
\text { dimiliki. }\end{array}$ & $\begin{array}{l}\text { Baik. } \\
\text { Mitra meskipun } \\
\text { masih belum } \\
\text { dapat } \\
\text { mengembangkan } \\
\text { varian baru } \\
\text { namun terus } \\
\text { berusaha dan } \\
\text { mengadopsi } \\
\text { budaya inovasi } \\
\text { produk }\end{array}$ \\
\hline Pemasaran & $\begin{array}{lr}\text { Label dan } \\
\text { kemasan baru } \\
\text { diterapkan pada } \\
\text { produksi yang } \\
\text { dilakukan } \\
\text { Plastik } \\
\text { pengemasan } \\
\text { dipergunakan } \\
\text { dengan yang } \\
\text { lebih tebal } \\
\text { Manajemen } \\
\text { permintaan } \\
\text { untuk pesanan } \\
\text { luar kota }\end{array}$ & $\begin{array}{l}\text { Sangat baik. } \\
\text { Aktivitas } \\
\text { pemasaran sudah } \\
\text { aktif dan } \\
\text { membuka lahan } \\
\text { pemasaran baru }\end{array}$ \\
\hline $\begin{array}{l}\text { Pemasaran } \\
\text { Online }\end{array}$ & $\begin{array}{l}\text { Aktif } \\
\text { menggunakan } \\
\text { kiat dalam } \\
\text { pemasaran } \\
\text { online dengan } \\
\text { menggunakan } \\
\text { akun khusus } \\
\text { toko dengan } \\
\text { label mitra } \\
\text { khususnya pada } \\
\text { pemasaran } \\
\text { dengan } \\
\text { menggunakan } \\
\text { instagram. }\end{array}$ & $\begin{array}{l}\text { Cukup baik. } \\
\text { Meskipun } \\
\text { implementasinya } \\
\text { belum dapat } \\
\text { dilaksanakan } \\
\text { dengan mandiri, } \\
\text { ketertarikan } \\
\text { mitra pada } \\
\text { perkembangan } \\
\text { zaman dan } \\
\text { teknologi sangat } \\
\text { baik }\end{array}$ \\
\hline $\begin{array}{l}\text { Pengembangan } \\
\text { Kelompok }\end{array}$ & $\begin{array}{l}\text { Mitra } \\
\text { mengembangkan } \\
\text { usaha sehingga } \\
\text { mampu } \\
\text { mempekerjakan } \\
\text { tiga orang tenaga } \\
\text { kerja }\end{array}$ & $\begin{array}{l}\text { Baik. } \\
\text { Terjadi } \\
\text { perkembangan } \\
\text { kelompok } \\
\text { menjadi lebih } \\
\text { besar dan } \\
\text { memberdayakan } \\
\text { masyarakat } \\
\text { sekitar }\end{array}$ \\
\hline $\begin{array}{l}\text { Peningkatan } \\
\text { Produktivitas }\end{array}$ & $\begin{array}{l}\text { Terjadi } \\
\text { peningkatan } \\
\text { produktivitas } \\
\text { bulanan hingga } \\
\text { mencapai kurang } \\
\text { lebih 150kg per } \\
\text { bulan }\end{array}$ & Sangat Baik. \\
\hline
\end{tabular}

\subsection{Perkembangan Ipteks Produksi}

Keluhan mitra selama proses produksi adalah berkaitan dengan ergonomi penggorengan dan kompor gas yang tidak nyaman sehingga membebani punggung 
Prihatin. et.al. Peningkatan Ekonomi Masyarakat Desa Sei Rotan Melalui Optimisasi Manajemen Usaha Kelompok Kerupuk Rengginang

pada saat kegiatan produksi. Dalam pelaksanaannya, kini mitra mulai mempergunakan kompor satu tungku sehingga aktivitas penggorengan dapat dilakukan dengan lebih santai. Perkembangan ini sangat membantu efisiensi kerja dari mitra.

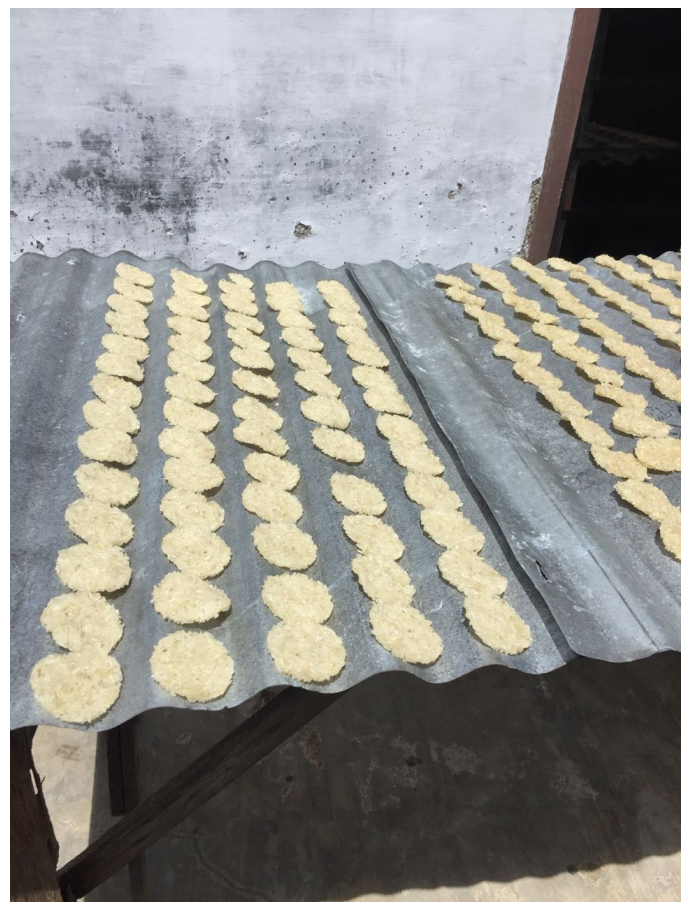

\section{Gambar 3 Proses Penjemuran Renggingar}

Proses penjemuran rengginang yang dilakukan oleh mitra dilakukan dengan metode sinar langsung matahari. Metode ini sangat sensitif terhadap kondisi sinar matahari. Elemen panas matahari merupakan peluang sekaligus ancaman bagi mitra. Panas matahari dapat meningkatkan rasa khas dari rengginang. Pengalaman mitra mengindikasikan bahwa rengginang yang dijemur di bawah matahari akan lebih baik dari segi kualitas dan rasa dibandingkan dengan faktor lain yang tidak menggunakannya. Sayangnya, ketergantungan pada matahari yang sangat tinggi juga menjadi kelemahan proses produksi ini. Bilamana matahari tidak muncul, proses produksi menjadi terhambat. Situasi ini menjadi tantangan bagi dunia akademisi dan inovasi agar dapat mengoptimalkan pemanfaatan tenaga surya, misalnya alat yang dapat menyerap mentari dan digunakan sebagai pengganti saat matahari tidak muncul. Tantangan ini tidak dibahas lebih lanjut dalam kegiatan pengabdian kali ini. Kendala teknis dan kemampuan dari tim pengabdian adalah permasalahan dalam pemanfaatan ipteks tersebut.

Banyak kemajuan yang telah dicapai mitra. Produksi mitra menjadi lebih efisien dengan peningkatan volume produksi. Perbaikan ergonomi proses produksi membantu mitra dalam meningkatkan volume produksinya. Cuaca merupakan faktor yang tidak dapat dikendalikan. Mitra mulai mencoba menginvestasikan uangnya untuk pembelian alat tersebut. Hal ini dilakukan untuk menjaga konsistensi pasokan produk ke pasar. Berkaitan dengan inovasi produk, hasil yang cukup memuaskan dicapai oleh mitra. Meskipun belum berhasil menghasilkan varian rasa rengginang yang baru, semangat inovasi mitra belum pudar. Mereka terus berupaya mengembangkan produk sembari menjaga varian original dari rengginang tersebut.

\subsection{Perkembangan Ipteks Pemasaran}

Terjadi perubahan yang cukup signifikan dari perilaku pemasaran mitra. Penggunaan label dan kartu nama sangat membantu mitra memperkenalkan produknya kepada masyarakat. Area pemasaran tidak hanya di pasar setempat, namun sudah mulai menerima pesanan dari luar kota. Mitra masih belum sepenuhnya terbiasa dengan fitur pemasaran online dan sedang berupaya mempelajarinya.

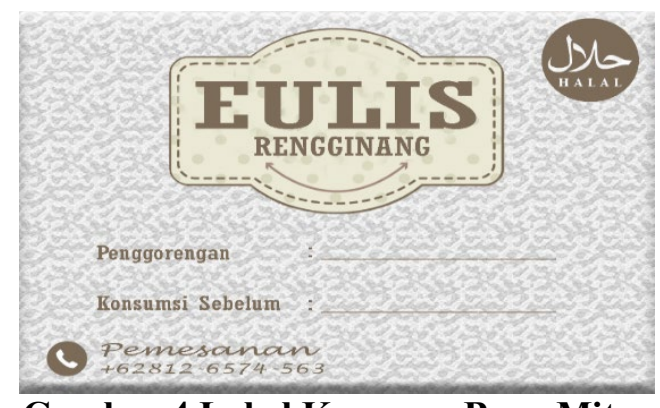

Gambar 4 Label Kemasan Baru Mitra 
Label mitra adalah label dasar yang dapat digunakan untuk media promosi sekaligus menjadi merek dagang mitra. Label tersebut berisikan infomasi mendasar yang diperlukan konsumen, seperti tanggal penggorengan, tanggal kadar luasa, informasi pemesanan produk, serta label halal produk. Elemen ini akan membantu kegiatan pemasaran mitra di masa yang akan datang.

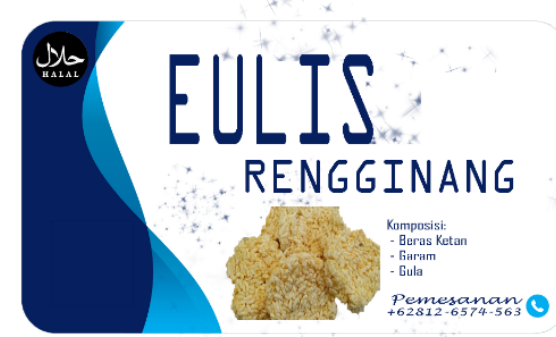

\section{Gambar 5 Desain Kartu Nama Mitra}

Kartu nama dipersiapkan pula untuk mendukung kegiatan pemasaran mitra. Kartu nama ini adalah salah satu cara pemasaran yang dapat diterapkan oleh mitra. Mitra tergolong aktif berorganisasi. Kartu nama dapat digunakan sebagai media promosi pada saat berorganisasi ataupun saat bertemu dengan konsumen potensial.

\subsection{Hambatan dalam Proses Pengabdian}

Kendala utama bagi mitra bagaimana mitra memasarkan produknya kepada pihak lain. Karena produk mitra adalah produk makanan maka kendala terbesar adalah perijinan IPRT, Sertifikasi Halal, Dan Sertifikat BPOM yang mana pengurusannya membutuhkan waktu yang lama terkait prosedur dan juga biaya yang mahal.

Kegiatan produksi dilakukan secara higienis dan menghindari penggunaan pengawet. Hasil pengamatan mitra, usia produk baik digunakan sebelum mencapai tiga bulan produksi. Rengginang (mentah) yang mencapai usia tiga bulan akan menguning dan dapat mengurangi potensi kesehatan produk. Permintaan untuk produk rengginang sudah berkembang hingga ke luar Kota Medan. Akan tetapi, memenuhi permintaan pasar lebih sulit dirasakan mitra mengingat salah satu faktor produksi utama bagi mitra adalah sinar matahari. Di musim hujan atau kondisi cuaca ekstrim seperti saat ini sangat menyulitkan mitra melakukan manajemen produksi yang baik.

\section{KESIMPULAN DAN SARAN}

\subsection{Kesimpulan}

Kegiatan pengabdian yang telah dilaksanakan di Desa Sei Rotan menyimpulkan:

1. Produksi rengginang masyarakat Desa Sei Rotan, khususnya mitra pengabdian memiliki kualitas unik yang membedakannya dengan produksi rengginakng keluaran luar Sumatera. Produksi mitra memiliki kerapuhan dan rasa yang lebih kuat daripada produk lainnya, namun variasi produk yang lebih monoton hingga saat ini.

2. Etos kerja mitra untuk melakukan diferensiasi produksi sangat kuat, meskipun kini belum berhasil menciptakan varian rasa seperti yang dilakukan oleh pesaing dari luar Sumatera, mereka terus berjuang sembari tidak melupakan kualitas produksi yang dimilikinya

3. Mitra sangat antusias dengan kepedulian perguruan tinggi dalam mengembangkan usaha desa. Mereka bahkan mulai antusias untuk memperluas pasar tidak hanya pada pasar lokal, maupun dalam provinsi, mereka siap untuk menggapai pasar yang lebih luas lagi.

4. Kendala utama dalam konsistensi produksi adalah cuaca. Sinar matahari dipercaya sebagai salah satu faktor yang memperkuat rasa rengginang yang dihasilkan. Alat pengering yang dapat membantu kelancaran produksi cukup mahal dan cukup besar fisiknya sehingga sulit bagi mitra untuk 
mengambil keputusan membeli alat tersebut.

5. Aktivitas pemasaran dari UKM kecil dari desa seperti mitra pengabdian kali ini hampir dapat dinyatakan sebagai tidak ada. Sumber utama permintaan hanya dari lokal masyarakat setempat saja; meskipun demikian sejawat tetangga mitra pernah membawa rengginang ke luar Medan dan menarik permintaan baru. Ini mengindikasikan potensi besar dari produk yang dihasilkan namun belum dapat dioptimalkan mengingat keterbatasan aktivitas promosi mitra.

\subsection{Saran}

Dengan mengacu pada capaian kegaitan pengabdian, disarankan:

1. Keselarasan antara pemerintah, akademisi, dan pelaku usaha sangat penting dalam mendorong keberlangsungan usaha masyarakat. Kegiatan yang dilakukan akan tidak mencapai optimal bila sinergi ini tidak terjadi.

2. Potensi produk UMKM (sebagai contoh produk mitra) sangat tinggi, namun tidak terkelola dengan baik. Minimnya aktivitas pemasaran adalah salah satu penghambat efisiensi pelaksanaan kegiatan ekonomi. Produk UMKM dapat menembus pasar nasional bahkan internasional dengan adanya pendampingan pengelolaan UMKM yang lebih banyak lagi. Kegiatan pengabdian ini sangat baik bagi kelangsungan dan perkembagnan UMKM kita, khususnya di Sumatera Utara dengan berbagai potensi usaha yang ada.

3. Program pelatihan dan pendampingan, khususnya dengan metode sharing and discussion efektif dalam mengetahui masalah mitra dan mencari solusi bagi mitra. Oleh karena itu sangat disarankan pada kegiatan selanjutnya metode ini terus diterapkan sehingga tidak lagi terjadi komunikasi satu arah, namun komunikasi dua arah dengan membuka wawasan mitra.

\section{UCAPAN TERIMA KASIH}

Kegiatan pengabdian masyarakat yang telah dilaksanakan telah dapat diselesaikan dengan dan didapat hasil yang diharapkan dapat diadopsi oleh masyarakat. Dalam pelaksanaan kegiatan ini, tim peneliti banyak mendapat bantuan dari bebagai kalangan, sehingga kegiatan pengabdian ini dapat terlaksana. Sehubungan dengan hal tersebut, tim peneliti mengucapkan terima kasih kepada LPPM USU yang telah membiayai kegiatan ini.

\section{REFERENSI}

Agarwal, S. P., dan G Ashwandi. 2008. Policies and mechanisms for technology transfer to SMEs in a globalizing economy - Indian perspectives. India: Economic, Political and Social Issues. India: Nova Science Publishers

Ayyagari, M., T Beck, dan A Demirguc-Kunt. 2007. Small and Medium Enterprises Across the Globe. Small Business Economics 29, pp. 415-434.

Badan Pusat Statistik. 2016. Industri Mikro dan Kecil, diakses melalui bps.go.id

Bhhatia-Panthaki, P. A. 2007. Enterprise development in Zambia: Reflections on the missing middle. Journal of International Development, 9, 12.

Bloch, H., dan M Bhattacharya. 2016. Promotion of innovation and job growth in small and medium-sized enterprises in Australia: Evidence and policy issues. Australian Economic Review, 49(2), 192199

Kementrian Koperasi dan Usaha Kecil Menengah. 2015. Perkembangan Data UMKM dan Usaha Besar. http://www.depkop.go.id/

Kotler, Philip dan Kevin Lane Keller. 2012. Marketing Management, 14th Edition. New Jersey: Prentice Hall.

Lo, M.C., Y.C. Wang, C.R. Wah, dan T Ramayah. 2016. The critical success factors for organizational performance of SMEs in Malaysia: A partial least squares approach. Review of Business Management 18(61), 370. 
ISSN Printed Version: 2549-4341

ISSN Online Version: 2549-418X

ABDIMAS TALENTA 3 (2) 2018: 291-299 http://jurnal.usu.ac.id/abdimas

Prihatin. et.al. Peningkatan Ekonomi Masyarakat Desa Sei Rotan Melalui Optimisasi Manajemen Usaha Kelompok Kerupuk Rengginang

Olughor, R. J. 2015. Effect of Innovation on the Performance of SMEs Organizations in Nigeria. Management 2015, 5(3): 90-95.

Tamizharasi, G., dan N Panchanatham. 2010. Entrepreneurial attitudes among entrepreneurs in small and medium enterprises. International Journal of Innovation, Management and Technology, 1(4), pp 354-356

Ussahawanitchakit, P. 2012. Administrative innovation, technical innovation, competitive advantage, competitive environment, and firm performance of electronics businesses in Thailand, International Academy of Business and Economic. 12(1). 